Research Article

\title{
Production Activities and Value Chain Analysis of Sericulture in Western Inner Terai Region of Nepal
}

\author{
Sushma Sharma $^{1 *}$, Soniya Acharya ${ }^{1}$, Samikshya Regmi $^{1}$, Avishek Poudel, Gokarna Adhikari ${ }^{1}$
}

${ }^{1}$ Midwest Academy and Research Institute, Campus of Live Sciences, Nepal

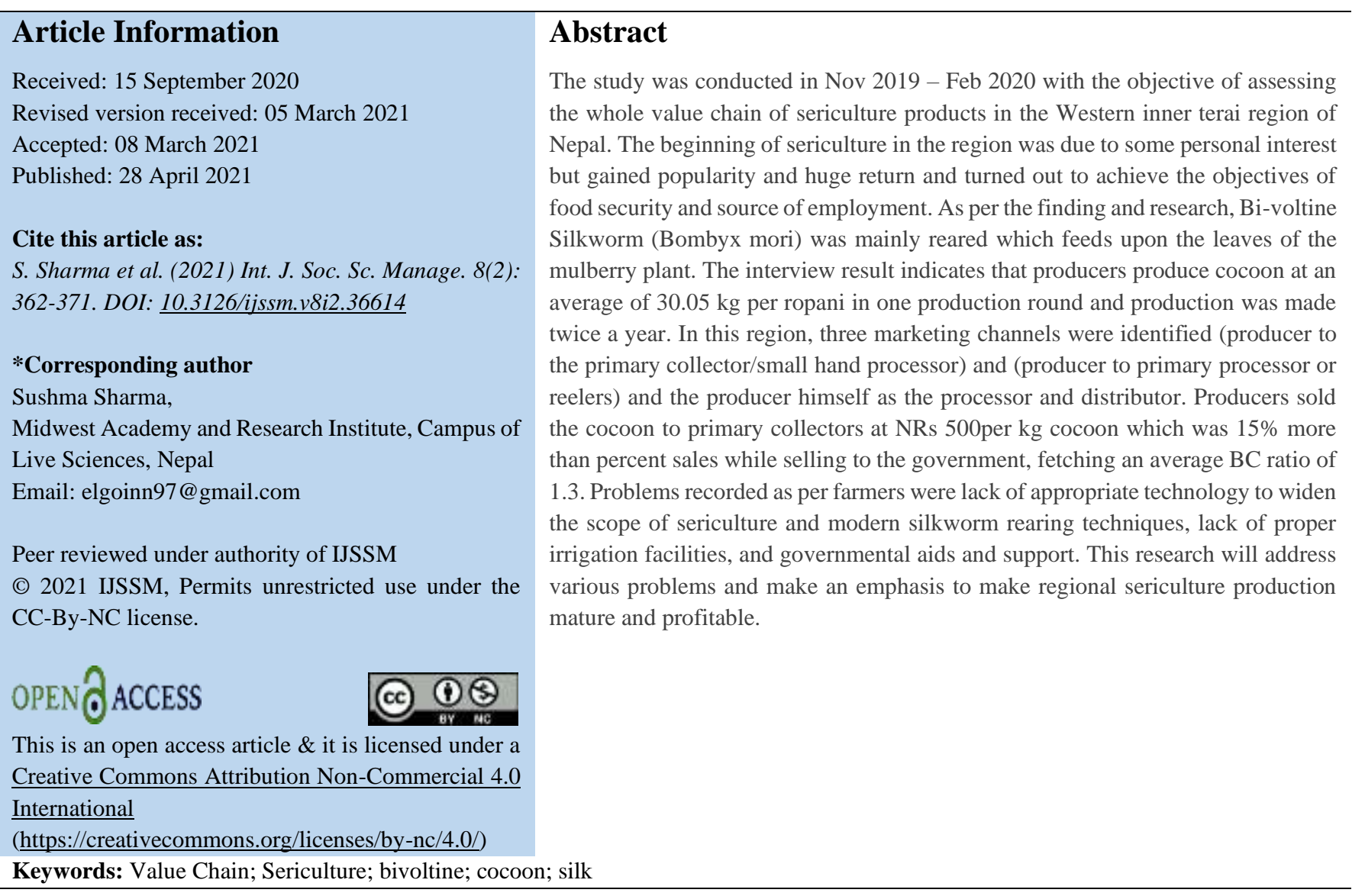

\section{Introduction}

Agriculture has been the major part of Nepalese economy as more than $65 \%$ of people are engaged in agriculture and it contributes $34 \%$ of total GDP (Chanotra et al., 2019). Among the different agricultural products produced and exported from Nepal, silk is growing as a competitive one. In Nepal, for achieving higher economic growth, agriculture and sericulture should be taken into parallel with each other (APP, 1995).
Silk is an agro-based industry. It involves rearing of silkworm (Bombyx mori) of various varieties for the production of raw silk, in which the yarn obtained out of cocoons spun by certain species of insects. The major activities of silk comprise the cultivation of feed plants popularly called mulberry to feed the silkworms that spin and reel the silk cocoons and finally unreeling the silk cocoons for adding edges of products by processing, 
weaving, and design. Sericulture has boundless advantages like high employment potential, provision of a platform for assisting rural economics, short gestation hence quick returns, women amiable and empowering occupation, ecofriendly and can stand out as an ideal scheme for weaker and vulnerable sections of society. Expectations for highvalue bivoltine silk as a new non-traditional export product that aims to remunerate and improve the income of Nepalese farmers including small scale farmers and farmers along the perimeter are sky-high. The most important and beautiful benefit of silk is that it can be practiced on small to medium-sized land following marginality. In this regard, silk can be one of the income-generating activities for rural communities in the Deukhuri region (Shrestha et al., 2012).

Silk is new agro-business technology for Dang and for various parts of the mid-hill region such as Dhankuta, Dhading, Palpa, Syangja, Parsa, Gulmi, Kavre that had been targeted as a tool for poverty reduction. 38 Districts of Nepal from Central Midlands of the Mid Hills altitude ranging from 750 to about 1500 meter, the slopes and valleys between the Mahabharata range and Shiwalik ranges (Kathmandu and Pokhara valleys) are declared to have topographic and climatic feasibility for sericulture. The Inner Terai region (Dang and Chitwan valleys) ranging from 100 to 750 meters are ideally suited for the development of the sericulture industry in Nepal as per various research and study were done by UNDP, FAO, JICA, and non-governmental organizations (GNRC, Sericulture) (Sattaur, 1994). But, in most of the regions, the sector is at the infant stage that requires focusing on both biological and physiological aspects. Since the sector has been untapped and lagged behind, research will be thoroughly conducted and hence fill the gaps existed. Hence, silk production and it's a promotion to enhance the income of low-level farmers, addressing and assessing the prevalent constraints in terms of production and marketing between all the actors should be conducted and this study was designed to assess the performances of silk production systems; to assess the status, opportunities, and constraints of silk production systems; to assess the marketing channel and constraints and opportunities of silk marketing (Madsen, 2012; Zheng \& Chen, 2003).

\section{Methodology of Research}

\section{Method of Data Collection}

A purposive sampling technique was used to conduct the study with a sample size of 10 household involving in sericulture and, were interviewed. Following the sampling technique, the necessary data were collected by administering pretested questionnaire to members of Sericulture Development Divison (SDD), Khopasi and a set of checklists and questionnaire to the selected respondents of study area for primary data collection. Pretesting was done by asking the initially designed questionnaire to some elite sericulture farmers and governmental institutions of the study area and the suggestions obtained from them were considered into our final questionnaire. assesses the production system of silk, the study focused on inputs of production-to-production management using forward and backward interviewing techniques. Both quantitative and qualitative methodologies were used to collect information from different actors involved in the value chain analysis of sericulture. The selection of farmers was made purposively based on their participation in silkworm rearing in coordination with the experts of the Sericulture Development Division (SDD). Since farmers involved in this sector are not accessible, well registered, and sustainable in the work, 10 accessible and better farmers of the Gadhawa Municipality located in the Dang District of Nepal were selected and used for the assessment (Kaplinsky \& Morris, 2000 \& 2008). A marketing study was conducted from the farm gate to the end-user (the processor) of the product across the value chain (Akram 2016; Koju, 2015).

Key Informants Interview (KII), Field Observations, and Structured questionnaires were used as the primary source of information. A visit was also made to the Sericulture Development Division, Khopasi, Kavre. A set of questionnaires was prepared to address the area for mulberry cultivation, amount of silk produced in the previous year, the current market price, silk processing, and marketing channels, production and marketing constraints, and were asked to the selected respondents of the study area to collect the primary data. Secondary source of information was collected from SDD, Reports from Sericulture Association Nepal (SAN), rapid market appraisal with the competent traders, buyers as well as whole sellers, and desk reviews of published and unpublished research articles and pape NRs (Thapa \& Ghimire, 2005).

\section{Method of Data Analysis}

\section{SWOT Analysis}

It is a strategic tool which is used for evaluation of position of a farm enterprise or a company for the clear manifestation of waves of both internal and external factors which eventually help or arrest the firm's growth or success. So, a SWOT analysis entails firm's strengths, weaknesses, opportunities and, threats. Both strengths and weaknesses are internal while opportunities and threats are external.

\section{Indexing}

After successive data collection from various sources, descriptive and quantitative analysis were done. Problems recorded in our study area were ranked accordingly with the use of index and scaling technique which provided the severity or extremities of the respondents towards our propositions. The intensity of productions and marketing problems related to silk and faced by the farmers were identified using three-point scaling technique comparing 
severe, moderate and slight using score 3,2 , and 1 respectively.

Formula for the index for intensity of various problems:

Iprob $=\sum(S i, f i / N)$,

Where, $I_{\text {prob }}=$ index value for intensity of problem, $\sum=$ summation, $S_{i}=$ scale value of $i^{\text {th }}$ intensity, $f_{i}=$ frequency of $\mathrm{i}^{\text {th }}$ response, $\mathrm{N}=$ total number of observations (Fig.1).

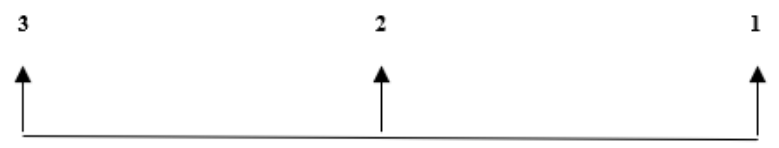

Fig. 1: Scale value for indexing of problems

In addition, different analyses were done to identify economies of production such as:

Gross margins

Total costs

$\mathrm{B} / \mathrm{C}$ ratio

\section{Results and Discussion}

\section{Benefit Cost Ratio}

Benefit cost ratio is the indicator that is used to calculate the profitability analysis.

It is calculated by using formula: B:C ratio = Gross return/ Total cost. Average B:C ratio in our study area was found

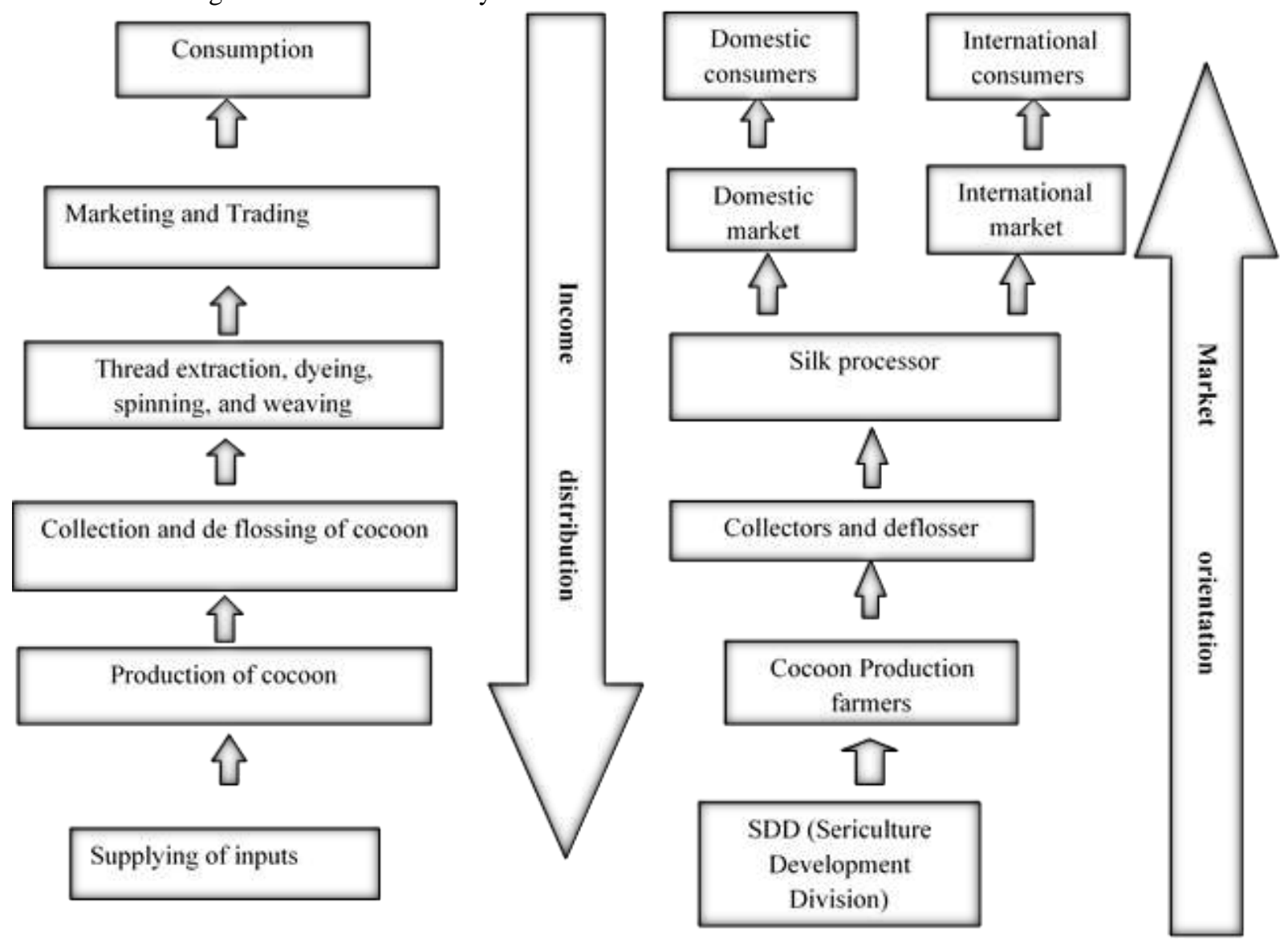

Fig. 2: Value Chain Map of sericulture. Adapted from Kumar \& Rajeev (2016). to be 1.38 , which shows the profitability in sericulture in that area.

\section{Gross margin analysis:}

Gross margin is the function of productivity, per unit price of output and total variable cost.

To calculate gross margin following formula is used:

Gross margin $=$ Sale margin - Variable cost

Average Gross margin NRs per ropani in our study area is 8542.63 and NRs per $\mathrm{kg}$ is 128.77 is found.

\section{Value chain map of sericulture}

Value chain analysis highlights that goods and activities are produced by different sequential sets of activities. Graphical illustration of all components and the relationship between the components is performed by a value chain map shown in Fig. 2 (Kumar \& Rajeev, 2016).

\section{Current Market Channels of Sericulture}

Channels of value chain include a chain of business through goods and services are passed until it reaches the final consumer. In our study area, we mainly found 3 channels of the value chain of sericulture among which the second one is highly practiced (Tesfa et al., 2014) (Fig.3). 
1)

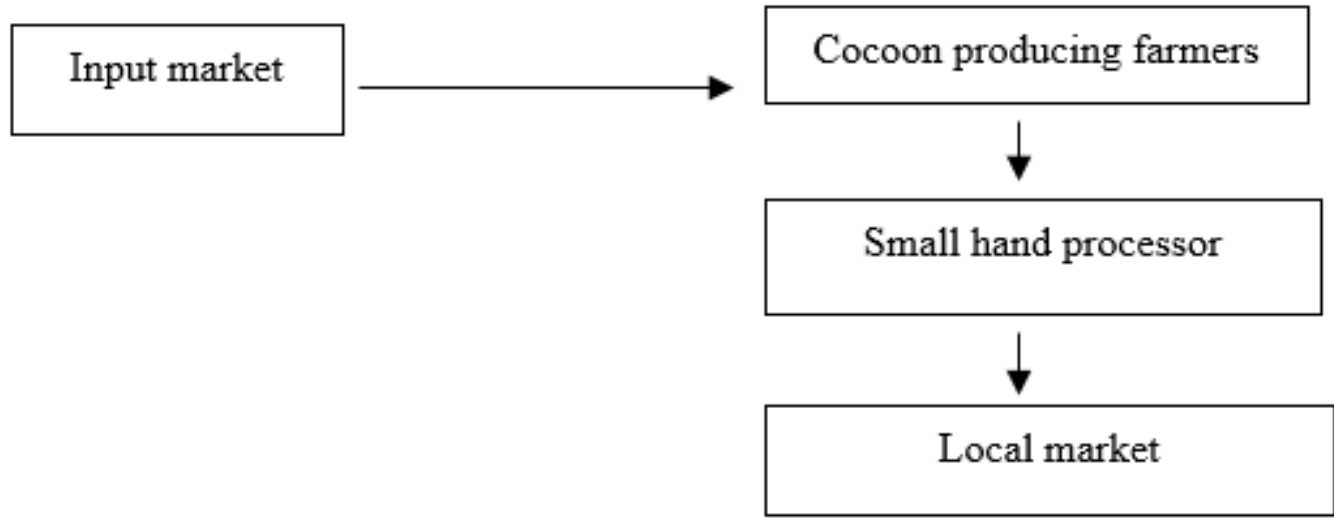

2)

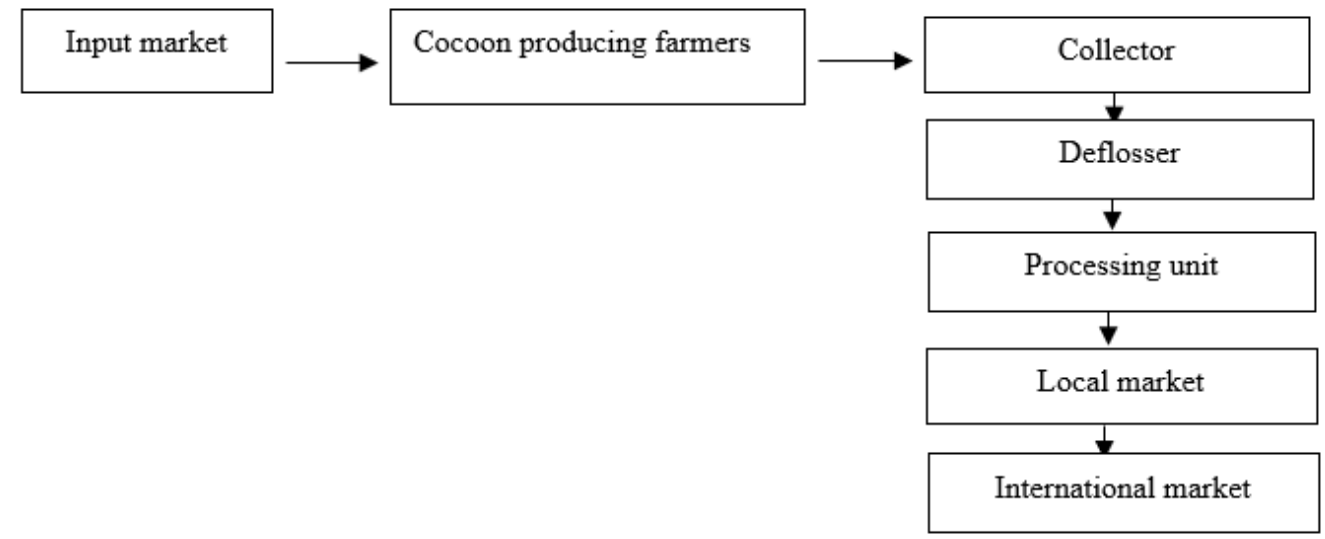

3)

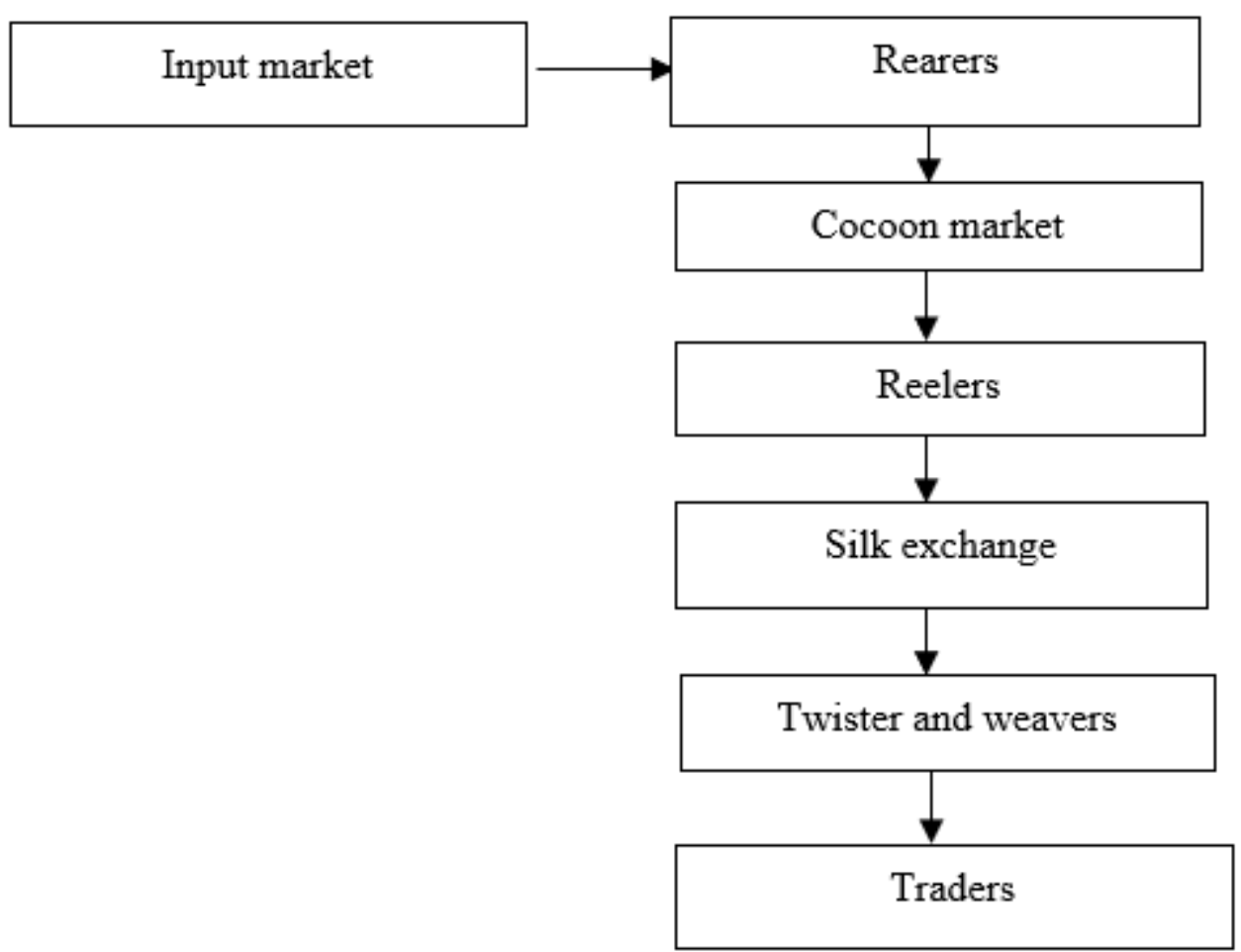

Fig. 3: Different value chain of silk in study area 


\section{Value Chain Perspective from Processing Factories}

The value chain map consists of production and distribution processes involving input supply, production, transportation/collection, processing, grading, and packaging and marketing both for domestic and export markets (Fig.4).

The production process begins after the fresh cocoon is harvested. Once silk cocoons are harvested, they are collected by deflosser for making raw silk, which are then sent to the processing unit for silk products. The prepared silk products are then sent to the domestic market and international market.

\section{Price spread of Silk}

Price spread is defined as the actual price paid by consumers, price gained by producers, cost incurred and profit margin gained by different agencies (Table 1).

There is the vast difference between price paid by consumers and the price received by producers due to the

Price distribution among different processing units such as small hand processor, collector and deflosser, reelers, twisters and weave NRs.

\section{Value Addition, Margin of Silk Different Chains}

Table 2 shows the movement of silk was not confined in a single channel. Different channels were observed from the beginning of production to the final marketing with different value addition activities. Value addition is gradual process in which the products get better in each step and gets valued. The product will get enhanced in terms of quality, it's usage value and a raw product finally becomes a finished goods. Several factors like processing, labor cost, designs, transportation affects the price of the finished commodity. These factors fix the price along with the profit margins (Fig 5).

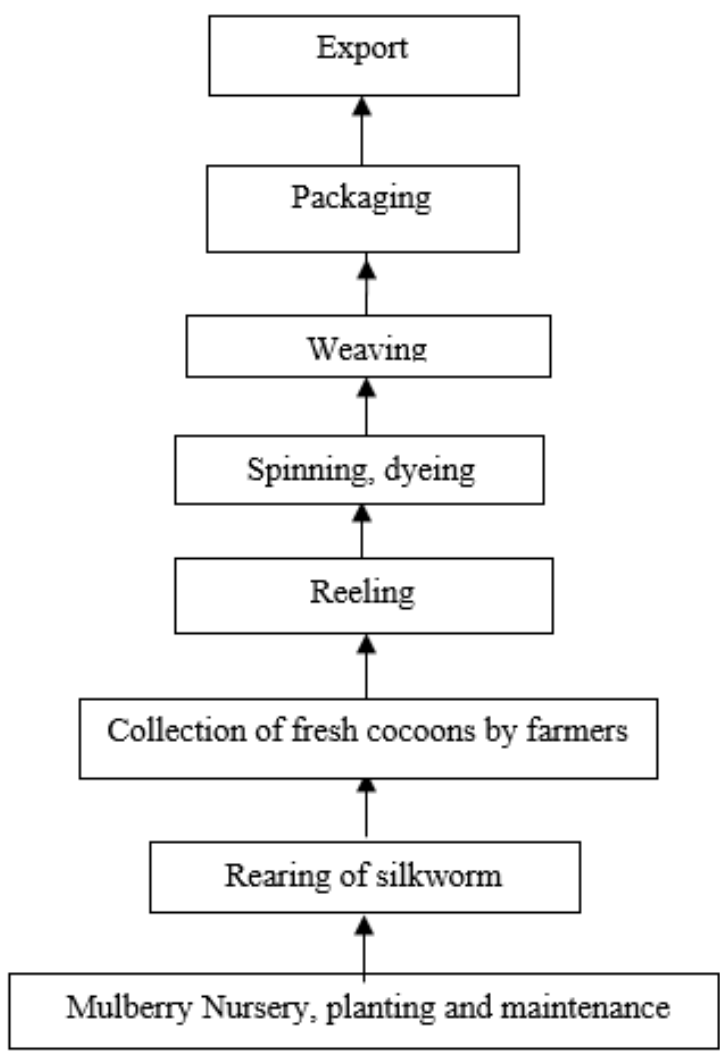

Fig. 4: Value chain of processing silkSource: Field survey (2020)

Table 1: Price spread of silk

\begin{tabular}{|c|c|c|c|c|c|c|}
\hline $\begin{array}{l}\text { Value } \\
\text { chains }\end{array}$ & $\begin{array}{l}\text { Local } \\
\text { producers }\end{array}$ & $\begin{array}{l}\text { Small hand } \\
\text { processors }\end{array}$ & $\begin{array}{l}\text { Collectors } \\
\text { and } \\
\text { deflossers }\end{array}$ & $\begin{array}{l}\text { Reelers, } \\
\text { twisters and } \\
\text { weavers }\end{array}$ & Processing unit & Local market \\
\hline 1. & $\begin{array}{l}\text { NRs. } 500 \text { per } \\
\text { fresh } \mathrm{kg} \\
\text { cocoon }\end{array}$ & $\begin{array}{l}\text { NRs. } 4225 \text { per } \\
\text { kg dyed yarn }\end{array}$ & - & - & - & $\begin{array}{l}\text { NRs. } 4225 \text { per } \mathrm{kg} \\
\text { dyed yarn }\end{array}$ \\
\hline 2. & $\begin{array}{l}\text { NRs. } 500 \text { per } \\
\text { fresh } \mathrm{kg} \\
\text { cocoon }\end{array}$ & - & $\begin{array}{l}\text { NRs. } 4225 \text { per } \\
\text { kg dyed yarn }\end{array}$ & - & $\begin{array}{l}\text { Rs } 9000 \text { per } \\
\text { finished product } \\
\text { made out of } 1 \mathrm{~kg} \\
\text { yarn }\end{array}$ & $\begin{array}{l}\text { Rs } 9000-25000 \\
\text { with } 10 \% \text { profit } \\
\text { margin based on } \\
\text { design of silk. }\end{array}$ \\
\hline 3. & $\begin{array}{l}\text { NRs. } 500 \text { per } \\
\text { fresh } \mathrm{kg} \\
\text { cocoon }\end{array}$ & - & - & $\begin{array}{l}\text { NRs. } 4550 \\
\text { per kg dyed } \\
\text { yarn }\end{array}$ & $\begin{array}{l}\text { Rs } 9000 \text { per } \\
\text { finished product } \\
\text { made out of } 1 \mathrm{~kg} \\
\text { yarn }\end{array}$ & $\begin{array}{l}\text { Rs } 9000-25000 \\
\text { with } 10 \% \text { profit } \\
\text { margin based on } \\
\text { design of silk. }\end{array}$ \\
\hline
\end{tabular}

Source: Field survey, 2019/20 


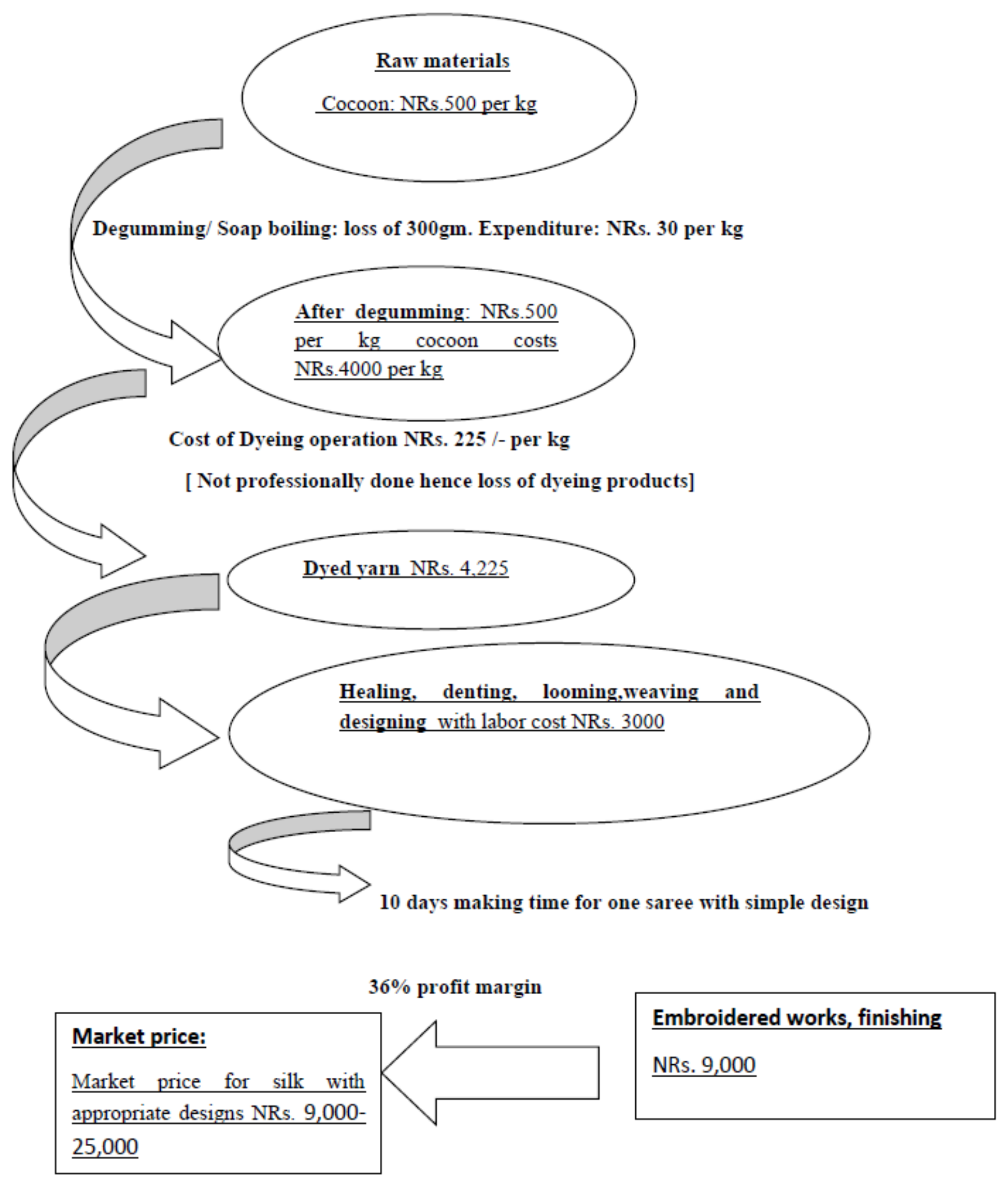

Fig. 5: Value addition of high value silk 
Table 2: Value chain actors; their roles and responsibilities in sericulture.

\begin{tabular}{|c|c|}
\hline Actors & Description \\
\hline Input Suppliers & $\begin{array}{l}\text { Input suppliers are the ones who supply all the essential materials or inputs required for the } \\
\text { production process. Silkworm eggs, saplings of mulberry plant and different tools and } \\
\text { equipments are the major inputs required. Eggs are solely produced and distributed to all the } \\
\text { producers by government. Saplings for the production of mulberry plants are locally available } \\
\text { in nurseries. }\end{array}$ \\
\hline Producers & $\begin{array}{l}\text { Producers are the actors who rear the silkworm eggs till it produces cocoon. They send the } \\
\text { cocoons further for primary processing. Most of the producers here are of small-scale type. } \\
\text { They produce cocoon and supply it to the primary process NRs. The rate is generally fixed by } \\
\text { primary processors and it is slightly higher than that recommended by government. }\end{array}$ \\
\hline $\begin{array}{l}\text { Collectors/Primary } \\
\text { Processors }\end{array}$ & $\begin{array}{l}\text { They are the actors in value chain who collect fresh cocoon produced by producers for further } \\
\text { processing. They perform the primary level of processing by reeling of fresh cocoon within } 24 \\
\text { hours to produce silk which is stored for few months before it is sold to secondary processing } \\
\text { facilities. } \\
\text { Different operations are carried out by processors such as deflossing, spinning, to produce silk } \\
\text { out of cocoon. Around } 500 \text { silkworms or } 80 \mathrm{~kg} \text { of cocoons and } 200 \mathrm{~kg} \text { of mulberry leaves are } \\
\text { required to produce } 1 \mathrm{~kg} \text { raw silk. Per kg price of cocoon costs NPR } 500 \text {. The end product, the } \\
\text { raw silk filaments, are reeled into skeins which are packaged into bundles weighing } 2-4 \mathrm{~kg} \text {, } \\
\text { called books. The books are further packaged into bales of } 60 \mathrm{~kg} \text { and transported to } \\
\text { manufacturing centeNRs. }\end{array}$ \\
\hline $\begin{array}{l}\text { Secondary } \\
\text { Processors }\end{array}$ & $\begin{array}{l}\text { They are the ones who buy raw silk from the primary processors and do further processing by } \\
\text { dyeing the silk for preparing garents etc. Secondary processing includes spinning, } \\
\text { degumming, dyeing, weaving. Silk clothes are the final product for export market. However, } \\
\text { for domestic market raw silk undergo further processing called real silk fabric. } \\
\text { Primary processing activities in Gadhawa is mostly carried out in Sunita Silkworm Rearing } \\
\text { Pvt. Ltd. And for secondary processing, it is sold to various industries in Kathmandu. } \\
\text { Main processing activities are reeling, thread extraction, dyeing, spinning and weaving. The } \\
\text { technological support is also provided by Sericulture Development Division, Kavre. }\end{array}$ \\
\hline Exporters & $\begin{array}{l}\text { Exporters are the actors responsible for exporting the silk fabrics or products. Sericulture } \\
\text { Association Nepal (SAN) is one of the major exporter unit. It does the processing and } \\
\text { exporting activities. The raw silk is exported to Korean company where further processing is } \\
\text { carried out and silk fabric is produced. Similarly, silk clothes are exported from Nepal to } \\
\text { different other countries. }\end{array}$ \\
\hline $\begin{array}{l}\text { Wholesalers and } \\
\text { Retailers }\end{array}$ & $\begin{array}{l}\text { Wholesalers and retailers are the final actors linking the products to the consumers in market } \\
\text { chain. Sericulture Association Nepal (SAN) which is one of the exporters, is also the } \\
\text { wholesaler unit which processes the raw silk and distributes to the retailers at reasonable price. } \\
\text { The retailers deal directly with the consumers i.e. the final product (silk products) is } \\
\text { distributed to the consumeNRs. }\end{array}$ \\
\hline
\end{tabular}

\section{SWOT Analysis}

SWOT analysis highlights an overview of the cocoon production in the various stages of the value chain. It identifies all the strengths, weaknesses, opportunities and threats throughout the process. Strengths and weaknesses encompass the internal factors whereas the opportunities and threats define the external factors related to the process. The SWOT analysis is displayed in the Table 3. 
Table 3: SWOT analysis of sericulture throughout the production and marketing.

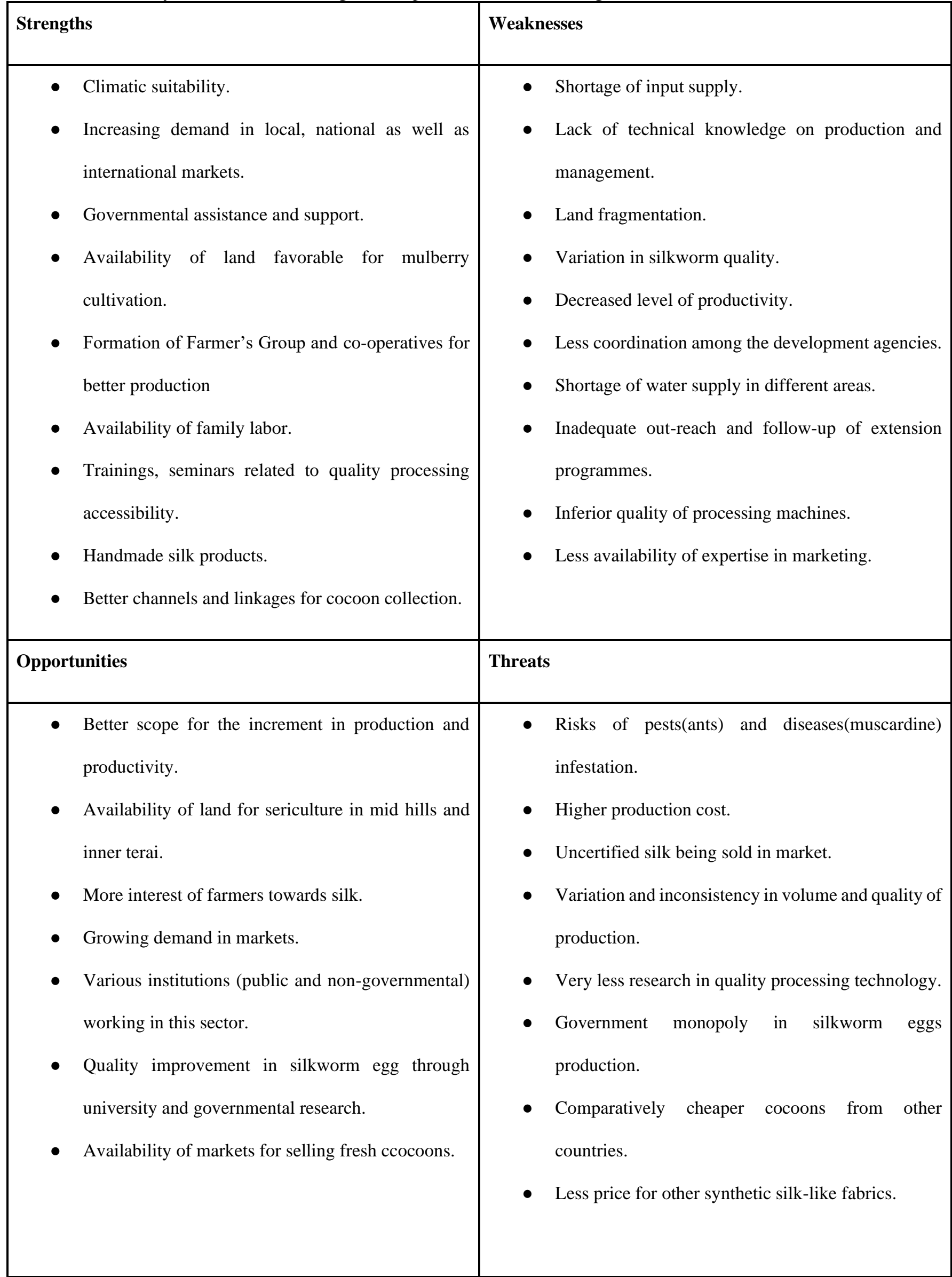




\section{Problems Faced by The Silkworm Producers}

Different production problems were perceived differently by silk growing farmers in the study areas. Financial problem got the first priority followed by problem of low technical knowledge, attack of insects (armyworm, stem borer) and occurrence of diseases (Table 4).

Table 4: Marketing problems faced by the silkworm producers

\begin{tabular}{|l|l|l|}
\hline Production Problems & Index value & Rank \\
\hline Insects and diseases & 2.4 & 2nd \\
\hline $\begin{array}{l}\text { Low technical } \\
\text { knowledge }\end{array}$ & 2.1 & 3 rd \\
\hline $\begin{array}{l}\text { Low Scale of } \\
\text { production }\end{array}$ & 1.8 & 5 th \\
\hline Climatic condition & 1.9 & 4 th \\
\hline Financial problems & 2.5 & 1 st \\
\hline
\end{tabular}

Source: Field survey 2019/2020

Note: Scale value ranges from 1 to 3 where, $1=$ low, $2=$ moderate, $3=$ high
Marketing problems include lack of transportation as the main problem followed by monopoly in price fixation, lack of awareness to domestic consumers and finally absence of middlemen to ensure the consistent supply (Table 5).

Table 5: Marketing Problems showing index values and their ranks

\begin{tabular}{|l|l|l|}
\hline $\begin{array}{l}\text { Marketing } \\
\text { Problems }\end{array}$ & Index value & Rank \\
\hline $\begin{array}{l}\text { Lack of } \\
\text { transportation }\end{array}$ & 2.4 & 1 st \\
\hline $\begin{array}{l}\text { Monopoly in price } \\
\text { fixation }\end{array}$ & 2.3 & 2nd \\
\hline $\begin{array}{l}\text { Lack of awareness to } \\
\text { domestic users }\end{array}$ & 2.2 & 3 rd \\
\hline $\begin{array}{l}\text { Absence of } \\
\text { middleman to ensure } \\
\text { the consistent supply }\end{array}$ & 2.1 & 4 th \\
\hline
\end{tabular}

Source: Field survey, 2019/20

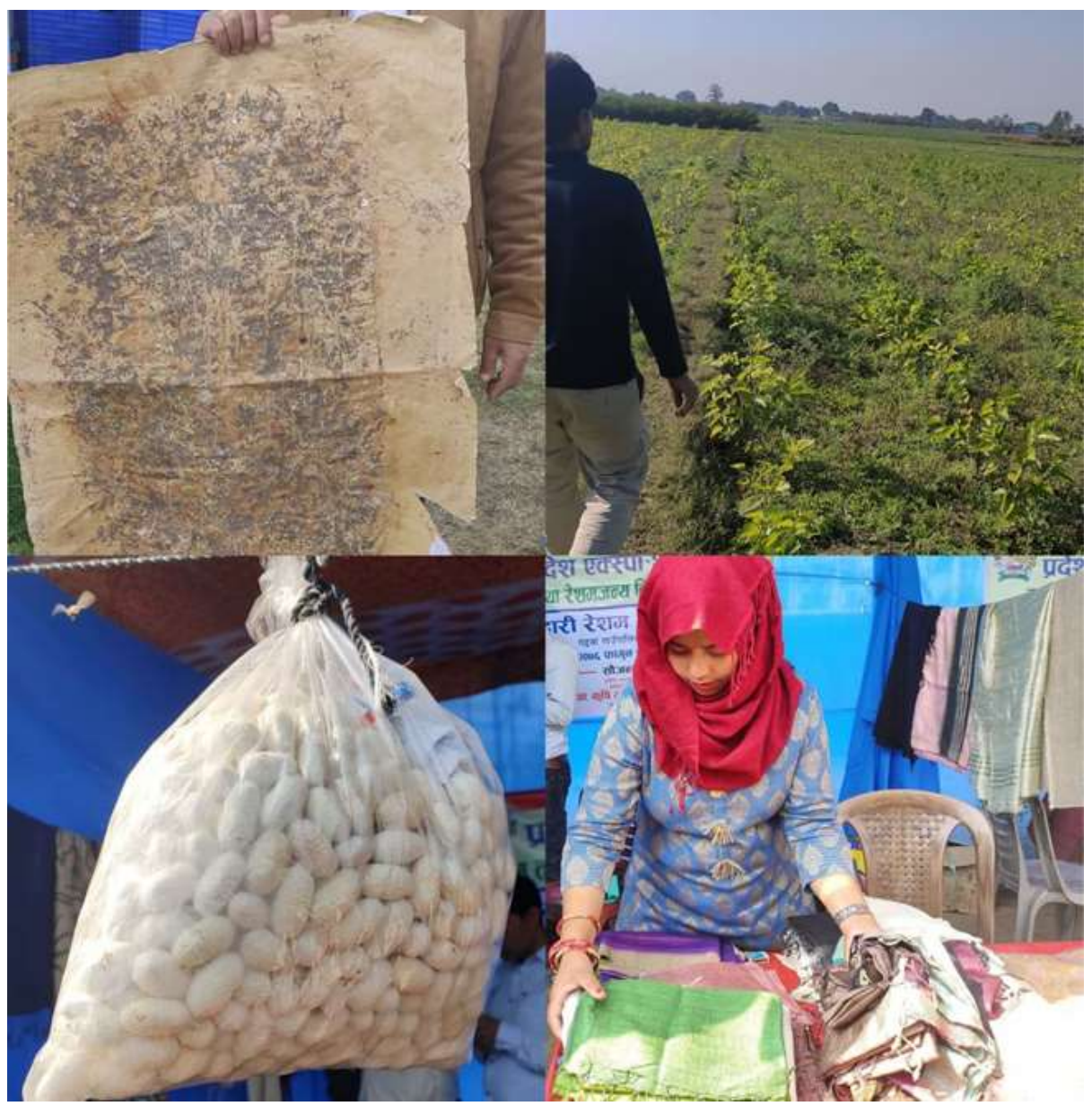

Fig. 6: Series of production of silk product in our study area viz., silkworm eggs, feeds for silkworms (mulberry), cocoon, and silk products. 


\section{References}

Akram S (2016) Analysis of the silk value chain in Pakistan. International Journal of Modern Trends in Engineering and Research (IJMTER) 8(2): 2349-9745.

APP (1995) Agriculture Perspective Plan APROSC and JMA Inc. National Planning Secretariat, Singh Durbar, Kathmandu. Nepal.

Chanotra S, Bali K \& Bali RK (2019). Sericulture: An opportunity for the up liftment of rural livelihood. Journal of Entomology and Zoology Studies 7(6): 1100-1103.

Gadal N, Thapa RB \& Kadariya RP (1996) Role of NGOs and INGOs in sericulture development in Nepal.

Kaplinsky R \& Morris M (2000) A handbook for value chain research (Vol. 113). Brighton: University of Sussex, Institute of Development Studies.

Kaplinsky R \& Morris M (2008) Value chain analysis: a tool for enhancing export supply policies. International Journal of Technological Learning, Innovation and Development 1(3): 283-308.

Koju S (2015). Hatchability, Disease Resistance and Quality of the Produced Cocoons among Five Selected Silkworm Races in Sericulture Development Division, Khopasi (Doctoral dissertation, Central Department of Zoology Institution of
Science and Technology Tribhuvan University Kirtipur, Kathmandu).

Kumar D \& Rajeev PV (2016) Value chain: a conceptual framework. International Journal of Engineering and Management Sciences 7(1): 74-77.

Madsen FS (2012) An Analysis of Global Silk Trade. Lund University, Department of Economics, Master's Thesis

Sattaur O (1994) Sericulture in Nepal: a handbook. Sericulture in Nepal: a handbook.

Shrestha JB, Chaulagain B \& Mainali RP (2012) Research highlights of sericulture in Nepal. J. Plant Protection Society 3: 50-52

Tesfa A, Ejigu K, Yetayew A \& Assefa H (2014) Assessment of value chain of sericulture products in Amhara region, Ethiopia. Int J Environ Eng Nat Resour 1(2): 61-69.

Thapa RB \& Ghimire NP (2005) Performance of mulberry silkworm (Bombyx mori L.) under leaf and shoot feeding methods. Journal of the Institute of Agriculture and Animal Science 26: 83-86.

Zheng JZ \& Chen GJ (2003) The strategic analysis on the silk industry in economy globalization. Commercial Research 13: 139-141. 